\title{
DEVELOPMENT OF WIND ENERGY COMPLEX AUTOMATION SYSTEM
}

\author{
Kuanysh Mussilimov ${ }^{1}$, Akhmet Ibraev ${ }^{1}$, Waldemar Wójcik ${ }^{2}$ \\ ${ }^{1}$ Satbayev University, ${ }^{2}$ Lublin University of Technology
}

\begin{abstract}
Wind power is one of the three main renewable energy sources, along with solar and hydropower, which are widely used to produce electricity worldwide. As an energy resource, wind is widespread and can provide electricity to much of the world, but it is both intermittent and unpredictable, making it difficult to rely on wind power alone. However, when used in combination with other types of production or in combination with energy storage, wind can make a valuable contribution to the global energy balance. Over the past few decades, wind power has emerged in a number of countries as a separate energy sector that has successfully competed with conventional energy. Attention is paid to wind power plants (WT) as part of distribution and transmission networks. In this regard, an urgent scientific and technical task is the efficient use of wind potential, which is not only to improve aerodynamic characteristics WT, but also to increase productivity WT as a whole. This article presents the type of wind turbines, among the possible applications and very promising is the wind turbine Bolotov (WRTB), which by its technical characteristics surpasses the traditional propeller and other installations using wind energy in the production of electrical energy. The increase (WEUF - wind energy utilization factor) in all modes of operation WT by improving various methods of automatic control is relevant, and the proposed work is devoted to this issue.
\end{abstract}

Keywords: wind energy, automation of wind turbines, wind farm monitoring

\section{OPRACOWANIE ZLOŻONEGO SYTEMU AUTOMATYZACJI ENERGETYKI WIATROWEJ}

\begin{abstract}
Streszczenie. Energia wiatrowa jest jednym z trzech glównych źródet energii odnawialnej, obok energii stonecznej $i$ wodnej, które są szeroko wykorzystywane do produkcji energii elektrycznej na calym świecie. Jako źródło energii, wiatr jest szeroko rozpowszechniony i może dostarczać energie elektryczna do wielu częśsi świata, ale jest on zarówno nieciagly, jak i nieprzewidywalny, co sprawia, że trudno jest polegać wyłącznie na energii wiatrowej. Jednakże w połaczeniu z innymi rodzajami produkcji lub w połaczeniu z magazynowaniem energii wiatr może wnieść cenny wkład w światowy bilans energetyczny. W ciagu ostatnich kilkudziesięciu lat energia wiatrowa pojawiła się w wielu krajach jako odrębny sektor energetyczny, który z powodzeniem konkurowat z energia konwencjonalna. Szczególna uwage zwraca się na elektrownie wiatrowe (EW) w ramach sieci dystrybucyjnych $i$ przesyłowych. W zwiazku z tym pilnym zadaniem naukowym i technicznym jest efektywne wykorzystanie potencjału wiatru, co ma na celu nie tylko poprawe właściwości aerodynamicznych turbin wiatrowych, ale również ogólne zwiększenie wydajności turbin wiatrowych. W artykule przedstawiono typ turbin wiatrowych, wśród możliwych zastosowań i bardzo obiecujący jest turbina wiatrowa Bolotov (WRTB), która swoja charakterystyka techniczna przewyższa tradycyjne śmigło $i$ inne instalacje wykorzystujace energie wiatrowa $w$ produkcji energii elektrycznej. Istotne jest zwięsszenie (WEUF - wind energy utilization factor) we wszystkich trybach pracy turbin wiatrowych poprzez udoskonalenie różych metod automatycznej kontroli, a proponowane prace poświęcone są tej kwestii.
\end{abstract}

Słowa kluczowe: energia wiatrowa, automatyzacja turbiny wiatrowej, monitoring farm wiatrowych

\section{Introduction}

Wind is a renewable, clean and endless source of energy, that meet demands of the growing energy in many countries. Thus, wind power is growing rapidly worldwide, especially over the past two decades, and the total installed capacity of wind power in the world has changed from $1.29 \mathrm{GW}$ in 1995 to $370 \mathrm{GW}$ by the end of 2015 [11]. Due to environmental considerations and the constant quest for energy security, this level will increase in nearest future, along with an increase in the size and installed capacity of wind turbines (WT).

Wind turbines have evolved from simple designs to complex multifunctional installations installed together in large arrays called "wind farms". The complexity of modern wind turbines necessitates a control system, which becomes a key component of a wind turbine to ensure safe and efficient operation of these complex wind energy conversion systems [5].

This is because, unlike other sources of energy, the wind cannot be regulated. Wind flow is largely a random process, variable both in time and space. This variability leads to difficulties in the transformation of energy, as WT is exposed to non-uniform and non-stationary resources, variable mechanical loads and nonlinear dynamics. Therefore, automatic monitoring and control systems are very important for WT. They allow to cope with wind variability and produce energy in a reliable and economical way. The main objectives of the control systems built into the WT are to maximize power generation, reduce dynamic and static mechanical loads and ensure uninterrupted power supply to the grid in accordance with the requirements of the power system. In order to achieve these goals WT should have operating control systems designed to regulate the parameters of turbines up to the desired target values [10]. Pitch angle of blades and torque of the generator are the main parameters subject to control in WT. Pitch adjustment allows to control the wind input torque to ensure uninterrupted power generation and reduce mechanical loads. On the other hand, generator torque control allows you to change the rotor speed of the BT in accordance with the maximum power point tracking (MPPT) strategy to extract as much energy as possible from the wind flow.

In addition, WT should also have network integration control to control the power supply to the network to ensure uninterrupted power supply. This is necessary because the integration of WT networks becomes a challenge because of the random nature of the wind, which can cause problems with network frequency stability [15].

Each of the above mentioned control systems (pitch control, generator torque control and grid integration control) has its own technology and methods that should be implemented depending on the operation modes of WT and their respective control purposes.

\section{WRTB automation}

Industrial generation of electricity is one of the most important priorities in the development of the Republic of Kazakhstan. The existing deficit in the generated capacity of power plants can be covered by the use of renewable energy sources (RES), the share of which in the country's energy sector is currently less than one percent. Potential wind energy reserves of Kazakhstan are incommensurable and theoretically exceed the total capacity of all currently operating power plants of Kazakhstan more than 300 times. All this makes the task of increasing the share of RES in the energy balance of the country very urgent $[1,3]$.

Among the possible types of wind turbines, the Bolotov Rotary Turbine (WRTB) is distinguished by its technical characteristics superior to traditional propeller and other installations using wind energy in the production of electrical energy. Advantages WRTB are the use of wind energy independent of direction (360 degrees), an extended range of wind speed from 2 to $45 \mathrm{~m} / \mathrm{s}$ and increased efficiency [8].

This paper deals with the creation of an automation system for the wind energy complex (WEC) using WRTB and, in addition, solar panels. 


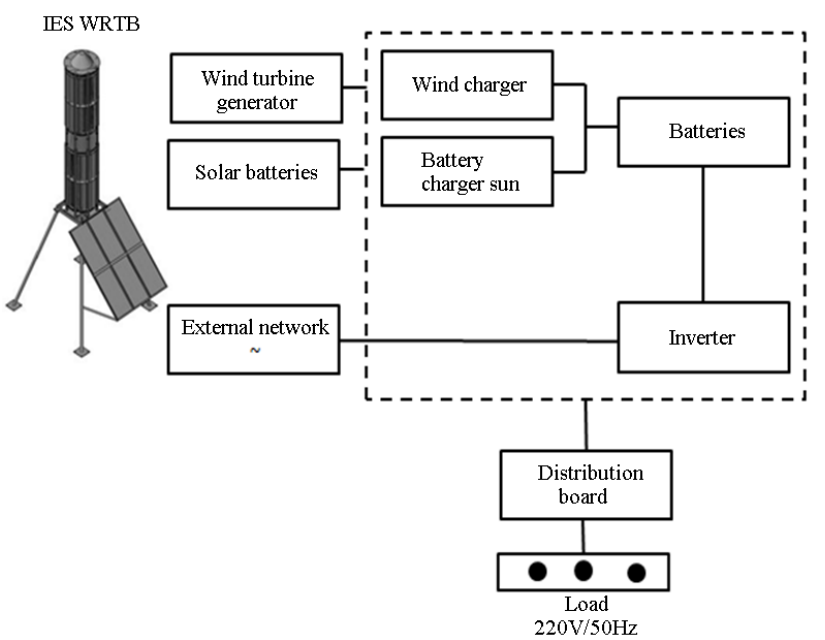

Fig. 1. Structural scheme of autonomous power supply system

The automation system under development is designed for automatic control and management of the wind energy complex (WEC). Automation objects covered by the automation system include both separate WRTB units and the whole complex. Automated types of activity are control of mechanical and electric variable units of WRTB, condition and position of equipment units, alarm system of deviation of variables and change of condition, centralized storage and presentation of information to personnel automatically and upon request, automatic and dispatch control.

The purpose of creating an automation system is to increase the efficiency of functioning WEC, which is provided by automatic control and operational monitoring of the state of equipment to reduce (or eliminate) undesirable and emergency modes of operation, to ensure the generation of electricity in specified parameters and quantities.

WRTB is a complex cylindrical structure with vertical arrangement of guides. An energy unit designed to generate electricity using wind energy to rotate the turbine rotor, which is mechanically connected to the generator rotor and consists of three parts: the turbine stator, the turbine rotor and the generator to generate electricity.

Anemometers are used to obtain information about wind speed and voltmeters and ammeters are used for electrical variables. The values of all measured variables are transmitted to the PLC. The automation scheme provides control of hydraulic pushers and magnetic starters.

In order to provide the consumer with qualitative and stable power, automatic switching on (off) of separate generators is provided.

The technical support of the automated process control system (APCS) WEC includes:

- measuring transducers, meters, etc.;

- actuators, including starters, limit switches, etc;

- programmable logic controllers;

- programmers;

- communication cables [12].

\section{Intelligent monitoring and analysis of turbine condition}

Wind turbines are generating units without the need for constant presence of personnel. They are often located in remote locations where the wind energy potential can be fully exploited. Given the size and complexity of today's wind farms, remote monitoring and modern diagnostic tools are a must.

\section{Round-the-clock monitoring of the turbine}

Wind turbines are equipped with a unique SCADA-system Genesis64. This system provides remote control, as well as the issuance of many variants of reports on the state of the turbine, viewed in a regular Internet browser. The status view displays information about the electrical and mechanical parameters of the turbine, its operation, failures, meteorological data, as well as the parameters of the electric substation. SCADA-system is connected to wind turbines and weather towers via the internal data transmission network. Depending on the needs, additional external equipment can be connected to the system. It regulates the output active power of wind turbines and acts as a "brain center" of the wind farm.

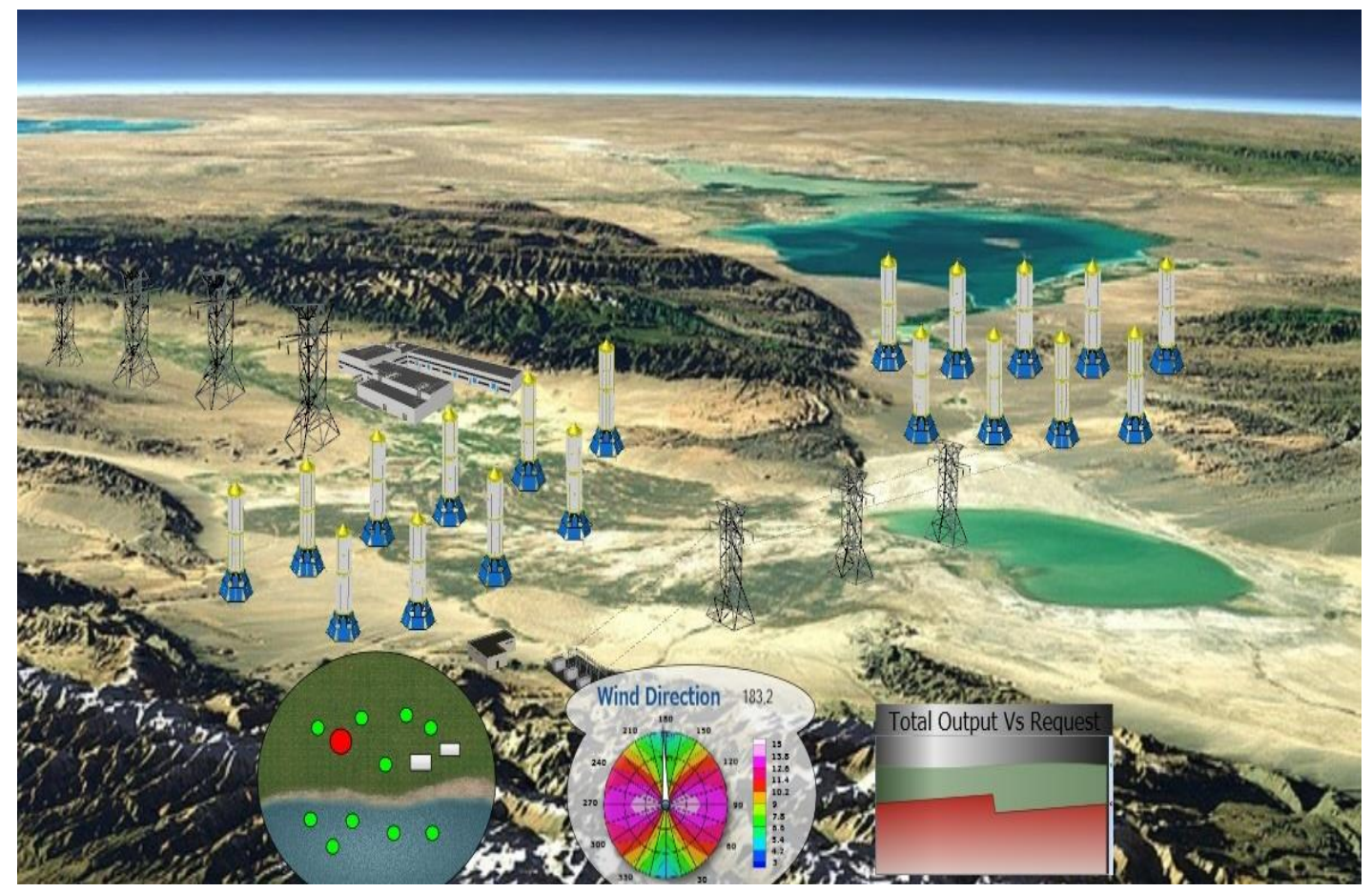

Fig. 2. SCADA-system for visualization of wind energy complex 


\section{Development of the wind power plant model}

The efficiency of the development process and design of control systems for complex objects depends on the use of simulation modeling, which will be shown on the example of development of a universal controller. The control system model should support programming in a high-level language to ensure that the control program is portable to the target system. MATLAB/Simulink package of programs for mathematical calculations from Mathworks Inc. has been chosen as a development and research environment, which is widely spread both in the scientific environment and in various design organizations [7].

The purpose of imitation modeling of computational experiment over computer models is to study the efficiency of WT when using different strategies and control algorithms.

The main characteristic influencing the efficiency of a wind power plant is the wind energy utilization factor (WEUF, further in the formulas and drawings designated as $C_{P}$ ) - the ratio of the mechanical power of the wind wheel to the total power of the wind energy passing through the ometable area of the wind wheel WT [2].

The computer model of the wind power plant was developed with a predetermined (WEUF) wind turbine and a universal con- troller to provide the possibility of changing the control algorithm, the functional scheme of the model is shown in Figure 3.

The peculiarity of the proposed model is the module of the controller of the wind power plant, working according to the userdefined algorithm [12]. Thus it is possible to allocate following ways of management applied in various types of wind turbines which are supported by computer model:

- wind turbine operating at a constant wind turbine speed;

- wind turbine operating at several fixed wind turbine speeds by switching generator windings;

- wind turbine operating at several fixed wind turbine speeds by switching the multiplier gear ratio;

- a wind turbine that operates at variable speeds and uses an electrical converter with a power regulator.

Calculation of the turbine output power is carried out according to the formula:

$$
P_{m}=C_{p}(\lambda, \beta) \rho A^{2} v^{3}
$$

where $P_{m}$ is the output power of the turbine (W), $C_{p}$ is the wind energy utilization factor (WEUF), $\lambda$ is the speed, $\beta$ is the angle of the rotor guides, $\rho$ is the density of air $\left(\mathrm{kg} / \mathrm{m}^{3}\right), A^{2}$ is the omnipresent area of the turbine $\left(\mathrm{m}^{2}\right), v^{3}$ is the wind speed $(\mathrm{m} / \mathrm{s})$.

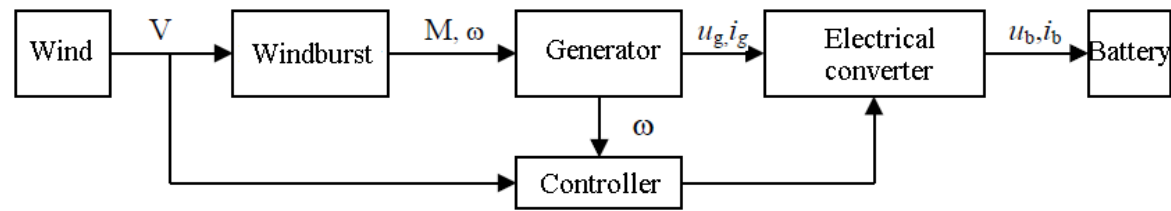

Fig. 3. Functional diagram of the simulation model of the wind power plant

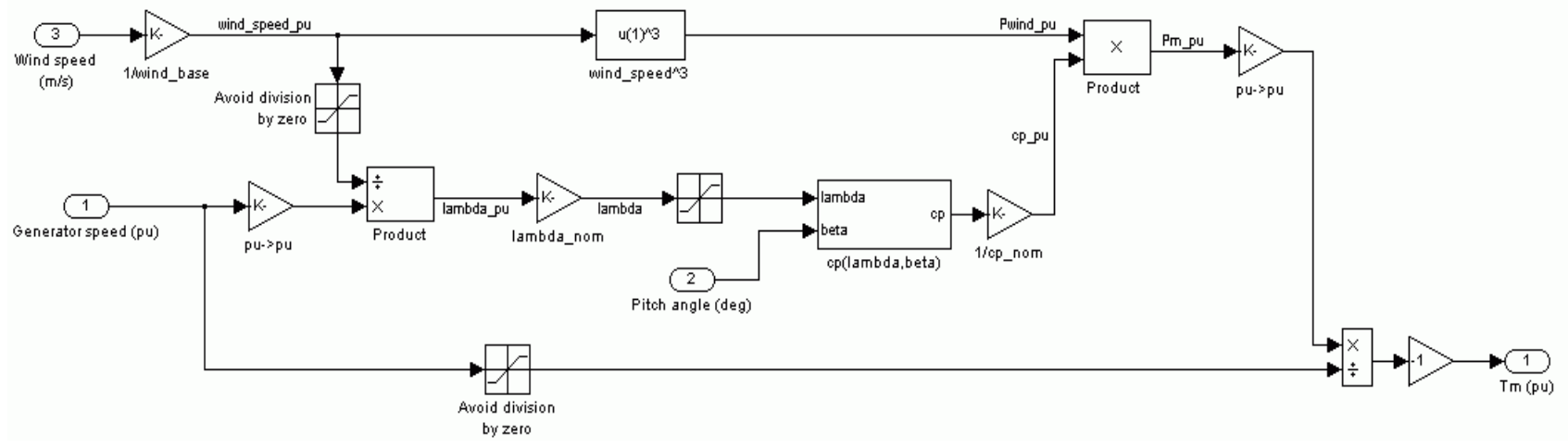

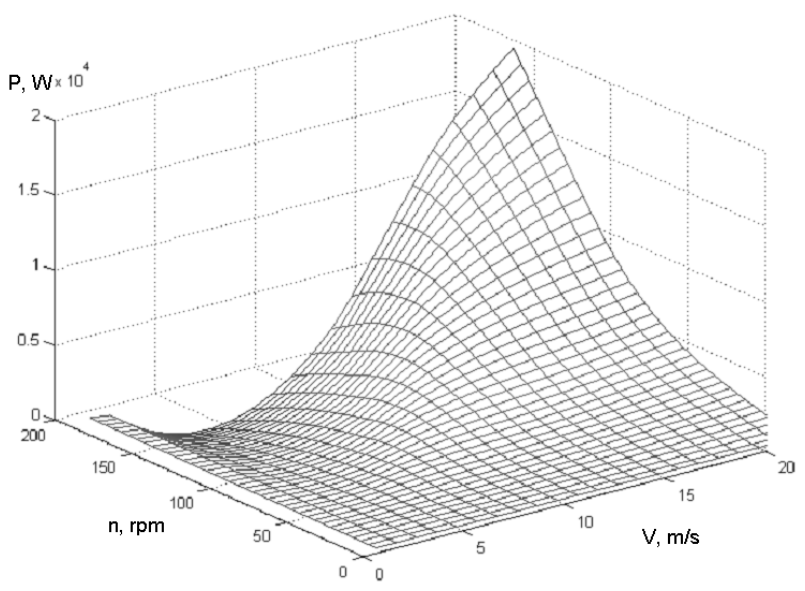

Fig. 5. Graph of rotor power distribution depending on wind speed and speed

\section{Description of the electric generator model of the wind power plant}

Electric generators are used in wind turbines to convert the mechanical energy of the wind turbine shaft rotation into electrical energy [9]. Electric generators used in wind turbines are subject to special requirements that take into account the peculiarities of their operation. One of the most important features is that the generator is driven into the rotation of the wind wheel, the speed of which depends on the wind speed and is not constant [13].

When changing the rotor speed of the generator and the alternating load, it is necessary to stabilize the voltage at the generator output, which creates the need for the use of voltage control device. This regulation is usually done by changing the current in the special excitation winding set by the voltage regulator. The use of the field winding leads to the need to increase the overall dimensions, as an additional space in the design of the generator to accommodate the windings. Also, the current in the field winding leads to additional electrical losses in 
the generator, sometimes reaching a value of $10 . .20 \%$ of the useful power.

Analysis of different types of electrical machines suitable for use in wind power plants shows that the choice of type and design of the generator is not unambiguous.

The development of a generator working together with the wind power plant control system has its own peculiarities [14]. The process of development of an electric machine for a wind power plant is significantly accelerated by modern computer facilities and appropriate software. At the stage of calculation of electromagnetic parameters and thermal calculations it is possible to use both engineering techniques for accelerated calculation and software packages based on the finite element method, such as Ansys EMAG or Maxwell [9]. At the design stage, solid-state modeling in computer-aided design systems like SolidWorks facilitates the developer's work.

Modeling of the generator of the wind power plant is carried out on the basis of studying of some features of the electric machine. The applied generator is a synchronous electric machine with excitation from permanent magnets and with axial direction of magnetic flow and ironless anchor containing stator windings [4]. The peculiarity of designing a generator with an axial gap is the absence of losses on the magnetization due to the lack of steel magnetic wire and low inductance of windings, the influence of which in the simulation of wind turbine can be neglected.

The following model of electric generator is proposed for simulation modeling of the algorithms of wind power control turbines in order to optimize the requirements to computational resources within the framework of the task. Based on the substitution scheme, the voltage of the generator phase winding is equal to

$$
u=e-r \cdot i-L \frac{d i}{d t}
$$

where $e$ electromotive force (EMF), $r$ active resistance of phase winding, $i$ current in phase winding, $L$ inductance of phase winding.

In order to reduce the influence of electric machine parameters resulted by the study of windings control algorithms it was assumed that $r$ and $L$ are equal to zero, and the electric current in the generator windings is set by the following equations:

$$
\left\{\begin{array}{c}
e_{A}=k \cdot \omega \cdot \sin (2 p \cdot \omega \cdot t), \\
e_{B}=k \cdot \omega \cdot \sin \left(2 p \cdot \omega \cdot t+\frac{2 \pi}{3}\right), \\
e_{C}=k \cdot \omega \cdot \sin \left(2 p \cdot \omega \cdot t-\frac{2 \pi}{3}\right)
\end{array}\right.
$$

where $e_{A}, e_{B}, e_{C}$ EMF of the corresponding generator windings, $k$ generator design factor, $2 p$ number of pairs of poles, $\omega$ generator rotor angle speed, $t$ time.

Figure 6 shows a block diagram of the generator model in the MATLAB/Simulink package.

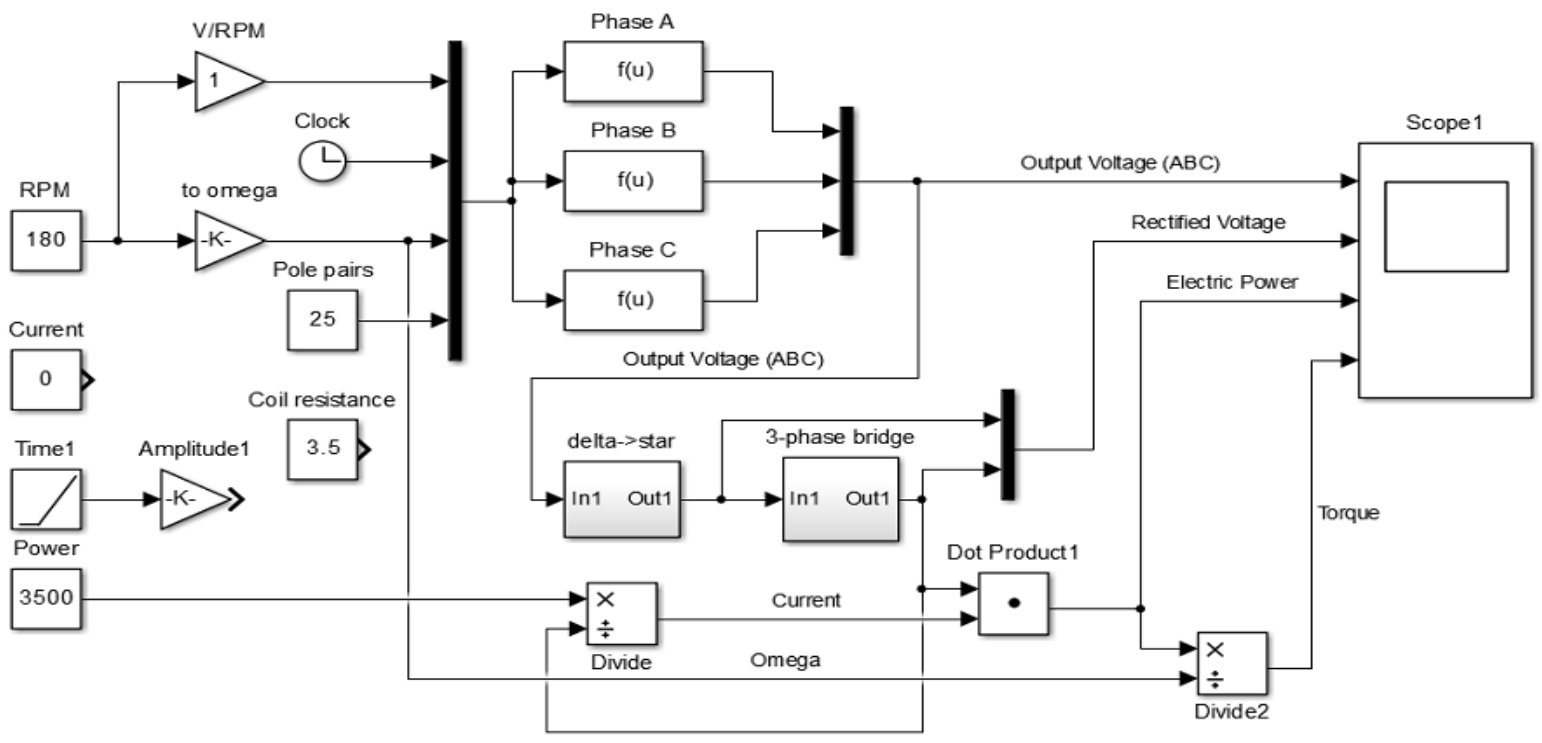

Fig. 6. Block diagram of the generator model
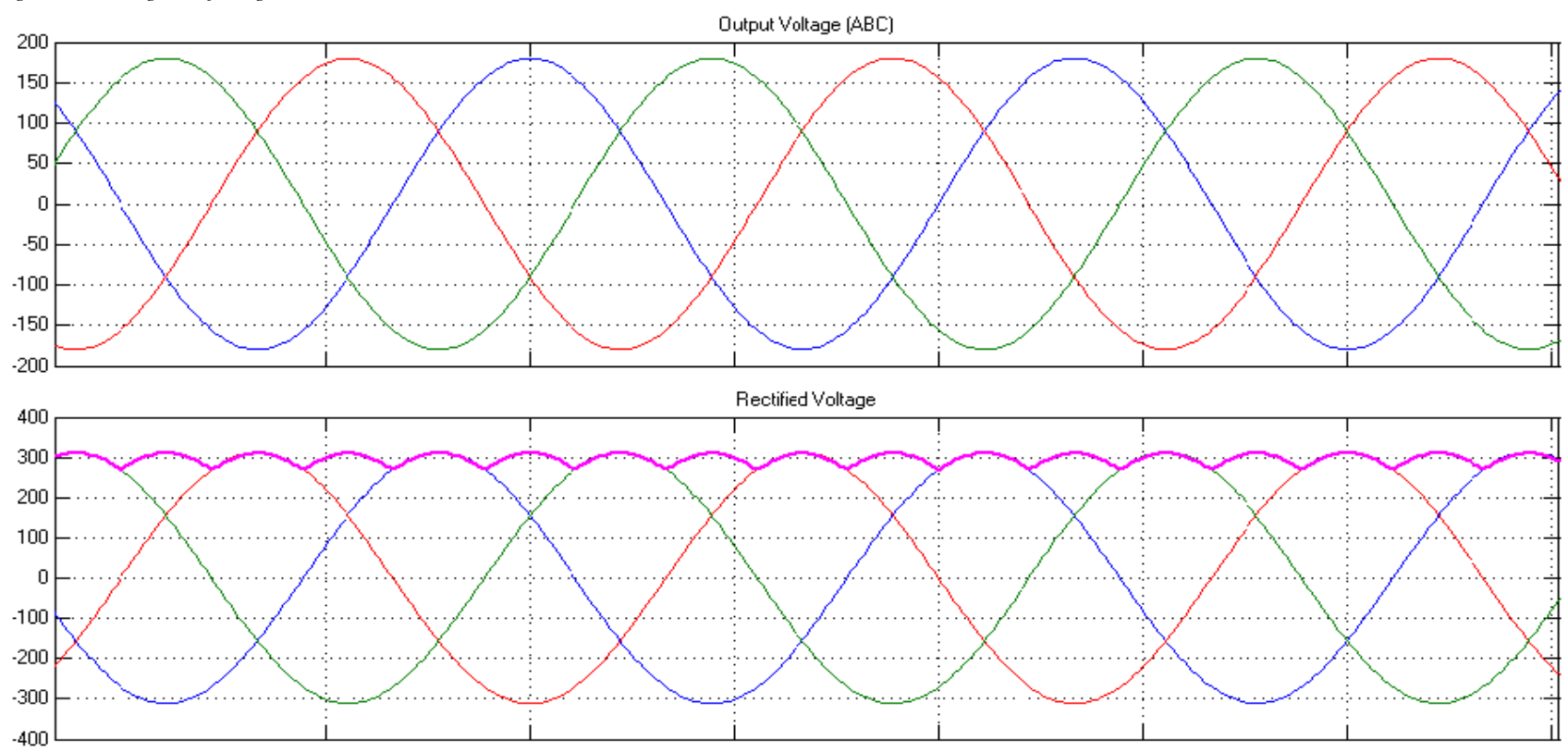

Fig. 7. Voltages on phase winding and rectifier output 

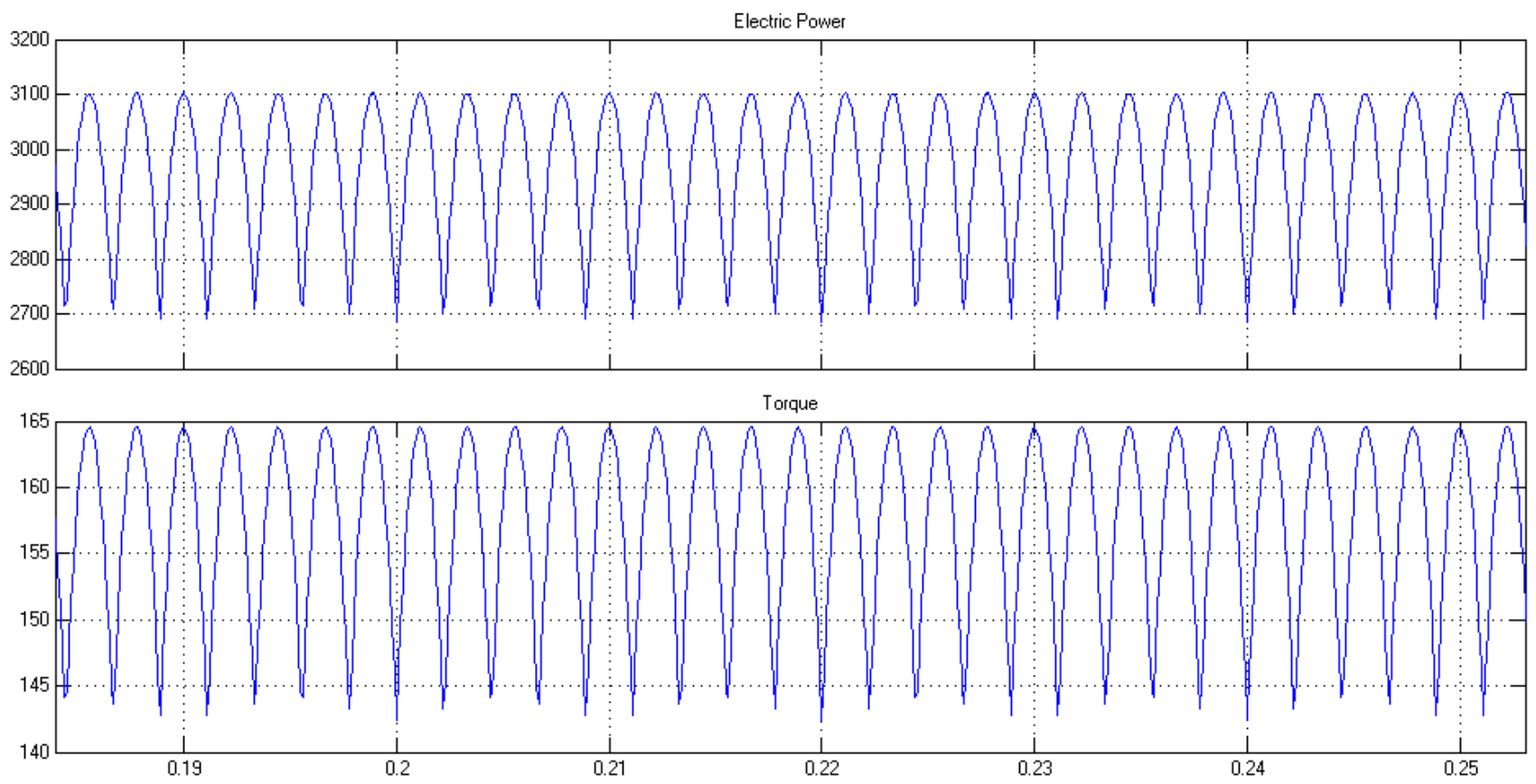

Fig. 8. The result of simulation of generator operation with a three-phase rectifier bridge on the load

Figure 7 shows the result of simulating the alternator at 180 rpm at idling speed. The upper graph shows the EMF in the generator phase windings and the lower graph shows the voltages at the rectifier input and output.

Figure 8 shows a simulation of the alternator at $180 \mathrm{rpm}$ and 10A load. The upper graph shows the electrical power of the generator, and the lower graph shows the electromagnetic pulsations.

The result of the numerical experiment showed that the use of a three-phase uncontrolled rectifier bridge leads to significant fluctuations in the electromagnetic moment of the generator because of the non-sinusoidal nature of the current of the phase windings of the generator. In order to eliminate the specified rectifier deficiency, the use of an active voltage rectifier as a load of the wind turbine generator is proposed, which allows to consider that the generator phase windings are loaded with active resistances. Then the current in the generator winding is sinusoidal and correspondingly in phase voltage in the appropriate winding, and the electromagnetic moment of the generator $M_{\mathrm{el}}=3 \cdot k \cdot I_{\Phi}$, where $I_{\Phi}$ the amplitude of the generator phase current.

\section{References}

[1] Bolotov A. V., Bakenov K. A.: Netraditsionnyye i vozobnovlyayemyye istochniki energii. Konspekt lektsiy dlya studentov vsekh form obucheniya spetsial'nosti 050718 - Elektroenergetika. AIES, Almaty 2007.

[2] Bolotov A. V.: Energosberezheniye: strategiya, taktika i tekhnologii. Vestnik Natsional'noy Inzhenernoy Akademii Respubliki Kazakhstan 1,2, 2014, 2015.

[3] Bolotov A. V.: Netraditsionnyye i vozobnovlyayemyye istochniki elektroenergii: Uchebnoye posobiye. AUES, Almaty 2011.

[4] Gandzha S. A., Martyanov A. S.: Metodika inzhenernogo rascheta ventil'nykh elektricheskikh mashin s aksial'nym magnitnym potokom. Vestnik YUUrGU. Seriya „Energetika” 13/2013, 85-87.

[5] Global wind report 2015. Gwec. Wind energy Technol. 75, 2016.

[6] Kopylov I. P., Klokov B. K. (red.): Spravochnik po elektricheskim mashinam. T. 1. Energoatomizdatm, Moscow 1989.

[7] Kozlitin L. S., Katsurin A. A.: Razrabotka sistemy upravleniya vetroenergeticheskoy ustanovkoy. Elektrotekhnika. Sb. tezisov dokladov nauchno-tekhnicheskoy konferentsii: Vologdinskiye chteniya, 1998, 14-15.

[8] Kukhartsev V. V.: Sovershenstvovaniye parametricheskikh kharakteristik energoeffektivnykh i ekologicheski bezopasnykh sistem kompleksnogo teploenergosnabzheniya avtonomnykh potrebiteley na baze vetroustanovok. Moscow 2005.

[9] Lubosny Z., Lubosny Z., Bialek J. W., Bialek J. W.: Supervisory control of a wind farm. IEEE Trans. Power Syst. 22/2007, 985-994.

[10] Manwell J. F., McGowan J. G., Rogers A. L.: Wind Energy Explained: Theory, Design and Application. Wiley 2010.

[11] Martynov N.N., Ivanov A.P. MATLAB 5.x: Vychisleniya, vizualizatsiya, programmirovaniye. KUDITS-OBRAZ, Moscow 2000.

[12] Matveyenko O. V.: Kompleksnaya programmno-matematicheskaya model' vetroenergeticheskoy ustanovki. Al'ternativnaya energetika i ekologiya 5(85), 2010, 64-70.
[13] Nikitenko G. V., Konoplev Ye. V., Konoplev P. V.: Stabilizatsiya chastoty vrashcheniya generatora vetroustanovki. Mekhanizatsiya i elektrifikatsiya sel'skogo khozyaystva 5/2012, 24-25.

[14] Sergeyev V. D., Kuleshov Ye. V.: Sinkhronnyy generator s postoyannymi magnitami dlya vetroelektricheskoy ustanovki. Materialy rossiyskoy konferentsii Avtonomnaya i netraditsionnaya energetika - Vladivostok 1998, 26-27.

[15] Yingcheng X., Nengling T.: System frequency regulation in doubly fed induction generators. Int. J. Electr. Power Energy Syst. 43/2012, 977-983, [DOI: 10.1016/j.ijepes.2012.05.039].

\section{M.Sc. Kuanysh Mussilimov}

e-mail: k-u-a@mail.ru

Kuanysh B. Mussilimov, born in 1994, PhD student at the Institute of Information and Telecommunication Technologies of the Kazakh National Research Technical University named by K.I. Satbayev, Almaty. Authored 4 publications. The area of his scientific interests is the Automation of the wind energy complex based on the Bolotov rotary turbine (WRTB).

ORCID ID: 0000-0002-8401-754

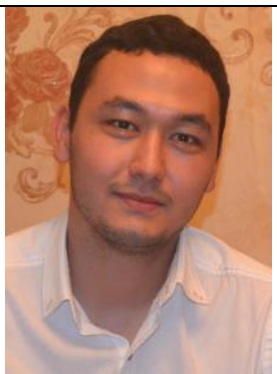

Prof. Akhmet Ibrayev

Akhmet Kh. Ibraev, born in 1946, defended his thesis on technical sciences (Ph.D.) in 1971, became an associate professor in 1975, an associate professor in 2016. Associate Professor, Department of Automation and Control, Kanysh Satbayev Kazakh National Research University, Republic of Kazakhstan. The author of more than 150 publications, 5 copyright certificates (patents), 3 textbooks. His research interests include the creation of automatic control systems, modeling and optimization of technological processes.

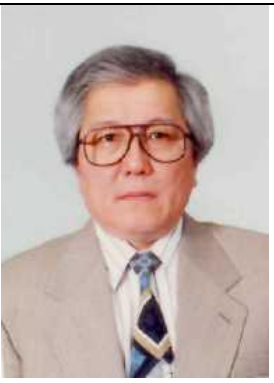

ORCID ID: 0000-0002-8474-0385

Prof. Waldemar Wójcik

e-mail: waldemar.wojcik@pollub.pl

Director of Institute of Electronic and Information Technologies, Faculty Electrical Engineering and Computer Science, Lublin University of Technology. His research interests include electronics, automatics, advanced control techniques, the optimization of the industrial processes, and fiber optic sensors including fiber Bragg gratings.

ORCID ID: 000-0002-0843-8053

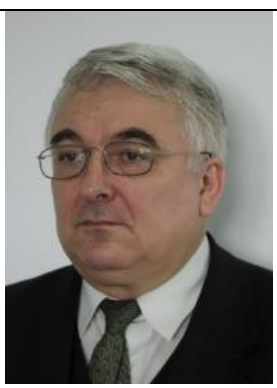

otrzymano/received: 15.05 .2019

przyjęto do druku/accepted: 15.06 .2019 